\title{
The Development of Upper Leaf Necrosis in Lilium 'Star Gazer'
}

\author{
Yao-Chien Chang ${ }^{1}$ and William B. Miller ${ }^{2}$ \\ Department of Horticulture, Cornell University, Ithaca, NY 14853-5904
}

AdDitional INDEX wORDs. lily, calcium deficiency, calcium nutrition, light reduction, leaf scorch, tipburn, leaf burn

\begin{abstract}
A necrotic disorder occurs on upper leaves of many oriental hybrid lily (Lilium L.) cultivars, including the most-widely-grown 'Star Gazer'. We term this disorder "upper leaf necrosis" (ULN) and hypothesize that it is a calcium $(\mathrm{Ca})$ deficiency. We demonstrated that $\mathrm{Ca}$ concentration in necrosed tissues was nearly six-fold below that of normal leaves $(0.10 \%$ vs. $0.57 \%$ dry weight), and that Ca concentration was negatively associated with percentage necrosed leaf area. It was concluded that ULN is a Ca deficiency disorder. When the symptoms were slight, early ULN symptoms appeared as tiny depressed spots on the lower surface of the leaf, or as water-soaked areas when the disorder was severe. Most commonly, ULN began on the leaf margin. The injured areas turned brown, leading to leaf curling, distortion, or tip death. ULN occurred on leaves associated with flower buds and leaves immediately below the flower buds. For the plants grown from $16-18 \mathrm{~cm}$ circumference bulbs, the five leaves directly below the flower buds and larger leaves associated with the 1st and the 2 nd flower buds were most susceptible. In general, flower buds were not affected by ULN, and continued to develop and flower normally, even though they were associated with subtending, highly distorted leaves. Eighty-five percent of plants began to exhibit ULN symptoms 30-40 days after planting (i.e., 24-34 days after shoot emergence). This was the stage when the 6th or 7th leaf under the bottom flower bud was just unfolded. Light was not the main factor that initiated ULN, however, ULN severity was greatly increased by light reduction, as leaf transpiration was reduced.
\end{abstract}

The oriental hybrid lily is an important plant grown for both cut flowers and pot plants. Although the culture of oriental hybrid lilies is relatively straightforward, a major anomaly occurs in many cultivars, including the most widely grown cultivar, 'Star Gazer'. The anomaly is characterized by necrotic tissues on upper leaves, with occasional leaf curling or distortion, resulting in reduced aesthetic appeal and consequently decreased economic value. We term this disorder "upper leaf necrosis" (ULN) (Chang et al., 2004; Chang and Miller, 2003, 2004). The disorder can be found in greenhouses in the United States (all regions, glass or plastic greenhouses, throughout the year), The Netherlands, and other countries. However, no systematic research has been performed to elucidate the symptom development and the causes of this disorder.

Several physiological leaf disorders are known on lilies. The most well-known is fluoride toxicity in easter lilies (Lilium longiflorum L.). This disorder is characterized by semi-circular necrotic areas on the leaf margin or tip on middle or lower leaves (Marousky, 1979) and has been termed "leaf scorch" (Marousky, 1979; Stuart et al., 1952), "tip-burn"(Dunham and Crossan, 1959), or "leaf burn" (Seeley, 1950). Another disorder, very different from fluoride scorch, was documented as early as 1979 in The Netherlands on the asiatic hybrid lily (Lilium) 'Pirate' (van Nes,

Received for publication 6 Apr. 2004. Accepted for publication 7 Mar. 2005. Use of trade names does not imply endorsement of named products nor criticism of similar ones not named. We thank Leon V. Kochian, Timothy L. Setter, and Anil Ranwala of Cornell Univ. for their sound advice on this project. Thanks to Mandayam V. Parthasarathy and Carole Daugherty of Cornell Univ. for their expertise and assistance in SEM work. This research was funded in part through a Specific Cooperative Agreement between the USDA-ARS Plant Protection Research Unit and the Cornell Department of Plant Pathology, Ithaca, N.Y. (SCA \# 58-1907-0035 ) funded by the USDA-ARS as part of the Floriculture and Nursery Research Initiative. We gratefully acknowledge the financial and material support from the Ministry of Education, Taiwan, the Fred C. Gloeckner Foundation, the Kenneth Post-Herman Schenkel Memorial Council, and the Royal Dutch Wholesalers' Association for Flowerbulbs and Nursery Stock.

${ }^{1}$ Former Graduate Research Assistant. Currently Assistant Professor, Dept. of Horticulture, National Taiwan Univ., Taipei 106, Taiwan.

2Professor and corresponding author; email: wbm8@cornell.edu.
1979). It appeared on glasshouse-grown plants when the stem was $35-50 \mathrm{~cm}$ long. While the upper leaves were affected, leaf distortion, as seen with ULN in oriental hybrids, was not typical of the disorder on asiatic hybrid lily. It tends to occur when elongation was most rapid and can result in withering of the whole inflorescence (van Nes, 1979). It was concluded the asiatic hybrid lily disorder was caused by a Ca deficiency (Berghoef, 1986; Berghoef et al., 1981).

The symptoms of ULN on oriental hybrid lilies are different from the two disorders described above. In The Netherlands, the disorder that we define as ULN is unfortunately also described as "leaf scorch." Since confusion can occur with the well-known leaf scorch caused by fluoride toxicity, we have used the term "upper leaf necrosis" in our research. Since the symptoms, such as marginal necrosis and leaf-tip death, are similar to those caused by Ca deficiency in other crops (Collier and Tibbitts, 1982; Simon, 1978), we hypothesized ULN is a calcium deficiency disorder. The objectives of this study were to describe how ULN develops and to assess the possible causes of this disorder.

\section{Materials and Methods}

Bulbs (16-18 cm in circumference) of the oriental hybrid lily 'Star Gazer' were planted in 15-cm-diameter plastic pots with 1 soil : 2 peatmoss : 1 perlite mix (by volume). The following amendments were added to the soil mix: $2.92 \mathrm{~kg} \cdot \mathrm{m}^{-3}$ dolomitic lime, $1.16 \mathrm{~kg} \cdot \mathrm{m}^{-3}$ gypsum, $0.58 \mathrm{~kg} \cdot \mathrm{m}^{-3}$ triple super phosphate, $0.88 \mathrm{~kg} \cdot \mathrm{m}^{-3}$ Micromax (Scotts-Sierra Horticultural Products Co., Marysville, Ohio), $0.28 \mathrm{~kg} \cdot \mathrm{m}^{-3}$ calcium nitrate, and $0.28 \mathrm{~kg} \cdot \mathrm{m}^{-3}$ potassium nitrate. Plants were grown in a greenhouse at Cornell Univ., Ithaca, N.Y., using standard cultural practices (Miller, 1992). The day/night temperature was set to $17 / 17^{\circ} \mathrm{C}$. Plants were fertigated with $15 \mathrm{~N}-2.2 \mathrm{P}-12.5 \mathrm{~K}$ fertilizer (Excel 15-5-15; Scotts-Sierra) at the concentration of $200 \mathrm{mg} \cdot \mathrm{L}^{-1} \mathrm{~N}\left(16 \mathrm{mg} \cdot \mathrm{L}^{-1}\right.$ ammoniacal nitrogen, $157 \mathrm{mg} \cdot \mathrm{L}^{-1}$ nitrate nitrogen, and $27 \mathrm{mg} \cdot \mathrm{L}^{-1}$ urea nitrogen). Calcium concentration in the fertilizer solution was $67 \mathrm{mg} \cdot \mathrm{L}^{-1}$. During the experimental period, daily light integral 
and greenhouse temperature were recorded using a data logger (LI-1400; LI-COR, Lincoln, Nebr.). A leaf was visually defined as "unfolded" when more than $75 \%$ of its leaf surface was not in contact with other leaves.

ULN CHARACTERIZING EXPERIMENTS. Three plantings of 'Star Gazer' lilies were made at 2-week intervals to observe ULN. Each planting consisted of 100 bulbs arranged in a completely randomized design (CRD). Planting dates of these three crops ("Spring Expt.") were 3, 17, and 31 Mar., respectively. Average fresh weights (FW) for bulbs in Crop 1, Crop 2, and Crop 3 were $67.4 \pm 0.5 \mathrm{~g}, 67.0 \pm 0.4 \mathrm{~g}$, and $66.8 \pm 0.4 \mathrm{~g}$, respectively. In a repeated experiment ("Summer Expt."), crops were planted 2, 16, and 30 Aug., with bulb FW of $67.3 \pm 0.5 \mathrm{~g}, 67.4 \pm 0.5 \mathrm{~g}$, and $67.2 \pm 0.4 \mathrm{~g}$, respectively. On 12 Oct., another 225 bulbs (67.0 $\pm 0.3 \mathrm{~g} \mathrm{FW}$ ) were planted for tissue analysis, soil analysis, and scanning electron microscopy ("Fall Expt.").

ShADING EXPERIMENTS. Open-frame chambers $(146 \mathrm{~cm}$ wide $\times$ $87 \mathrm{~cm}$ deep $\times 87 \mathrm{~cm}$ high) covered with black shade cloth were used to reduce light intensity within the greenhouse. The cloth covered the top of chambers, but only covered about half of each side wall to ensure the necessary air movement to prevent humidity build-up. Shading levels included 0\% (control), 30\%, and $55 \%$ light reduction. An individual chamber was considered an experimental unit; 21 plants were grown in each chamber in Expt. 1 and 29 plants in Expt. 2 in a CRD with three replications of each light level. The average bulb fresh weight of Expt. 1 was $66.8 \pm 0.3 \mathrm{~g}$, and Expt. 2, $62.7 \pm 0.3 \mathrm{~g}$. Expt. 1 began on 18 Sept., and Expt. 2 on 20 Nov. Shading treatments were applied 23-58 $\mathrm{d}$ after planting (DAP). During the treatment period, relative humidity $(\mathrm{RH})$ in the chambers was recorded at 15-min intervals by Hobo Pro data loggers (Onset Computer Corp., Pocasset, Mass.). Before the treatments started, these data loggers were placed on a greenhouse bench, shaded from direct sunlight, for $4 \mathrm{~d}$. The acquired data were then used to properly adjust the final $\mathrm{RH}$ values.

ULN INCIDENCE AND SEVERITY INDEX. The incidence of ULN occurrence was defined as the percentage of plants (or leaves at a specified location) that had any level of symptom expression. Because plants had different levels of symptom expression, to further refine differences between treatments, an index from 0 to 5, based on symptom progression and necrosed leaf area, was developed to describe the severity of necrosis on individual leaves. Representative leaves showing these symptoms are shown in Fig. 1, and are described as below:

$0=$ no visible necrosis symptoms

$1=$ chlorotic spots

$2=$ curled leaf margin

$3=$ marginal necrosis

$4=$ dead leaf tip

$5=>50 \%$ of the leaf area was necrotic

When the severity level was between two index categories, the average was used ( 0.5 was added to the lower value). The severity of the individual single leaves was then summed to give whole-plant severity. Examples of different whole-plant severity are given in Fig. 2. When whole-plant severity was less than 5 (as shown in Fig. 2B), the symptoms were very light, and would not be visible to the casual observer.

Tissue AND LEAF ANALYSIS. To assess mineral element concentration, six healthy and necrosed plants were randomly selected from the Fall Expt., 45 DAP, when plants were exhibiting early ULN symptoms. Necrosed tissue regions $\left(\approx 80 \mathrm{~mm}^{2}\right.$ each) were cut from the margins of three newly unfolded young necrosed leaves per plant and combined for one sample. Non-necrosed tissues were obtained from leaves of healthy plants at the same leaf location and margins. To investigate the relationship between leaf $\mathrm{Ca}$ concentration and necrosed leaf area, leaves representing each severity index category were randomly harvested from plants of the Fall Expt. on 45 DAP. Harvested leaves were rinsed three times in distilled water, and then oven-dried to constant weight at $70{ }^{\circ} \mathrm{C}$. About 100 to $400 \mathrm{mg}$ of dried tissue, depending on tissue availability, was weighed into a quartz tube, and dry-ashed at 450 ${ }^{\circ} \mathrm{C}$ for $6 \mathrm{~h}$. After cooling, $0.25 \mathrm{~mL}$ of $30 \%$ hydrogen peroxide was added to each tube and the sample was re-ashed for $2 \mathrm{~h}$. Hydrochloric acid $(37 \%, 0.5 \mathrm{~mL})$ was then added to dissolve the ash. After $1 \mathrm{~h}, 9.5 \mathrm{~mL}$ distilled water was added to the sample and mixed. Mineral element concentration in this solution was analyzed by Inductively Coupled Plasma Spectrometry [ICP (model 975; Thermo Elemental, Franklin, Mass.)]. Wavelengths used to determine $\mathrm{P}, \mathrm{K}, \mathrm{Ca}, \mathrm{Mg}, \mathrm{Fe}, \mathrm{Mn}, \mathrm{Cu}, \mathrm{B}, \mathrm{Zn}, \mathrm{Mo}$, and Ni were 214.9, 766.4, 317.9, 279.5, 259.9, 257.6, 324.7, 249.7, $213.8,202.2$, and $231.6 \mathrm{~nm}$, respectively.

SoIL ANALYSIS. Six pots were randomly selected from both healthy and necrosed groups 44 DAP to determine if a relationship existed between ULN incidence and medium fertility. Soil mix was sampled, dried and then extracted with Morgan's solution (Morgan, 1941). Activated carbon was added to help remove organic matter and to decolorize the extraction solution. The extraction was then filtered and analyzed by ICP.

TRANSPIRATION MEASUREMENT FOR SHADING EXPERIMENTS. Transpiration and photosynthesis were measured during a sunny day by the CIRAS-1 Portable Photosynthesis System (PP Systems, Hertfordshire, U.K.) on 51 DAP for Expt. 1 and 53 DAP for Expt. 2. Three plants were randomly selected from each chamber for this measurement. The leaf U1 (1st leaf under buds) was measured. If U1 was not available due to excessive tissue necrosis, U2 was measured. At the end of treatment (58 DAP), the three plants used for transpiration and photosynthesis measurement were harvested for dry mass and determination of Ca concentration of all leaves. All data acquired within each chamber were averaged and used as an observation for statistical analysis.

SCANNING ELECTRON MiCroscopy (SEM). Newly unfolded leaves were randomly sampled from both healthy and necrosed groups 34 DAP. Tissues were cut from leaf margins and processed for electron microscopy (Glauert, 1975). Briefly, the tissues were fixed in $2.5 \%$ glutaraldehyde in $0.1 \mathrm{M}$ sodium cacodylate buffer ( $\mathrm{pH}$ 6.8) for $2 \mathrm{~h}$ at $4{ }^{\circ} \mathrm{C}$, and washed in three 10-min washes of $0.1 \mathrm{M}$ sodium cacodylate at $4{ }^{\circ} \mathrm{C}$. Specimens were soaked overnight at $4{ }^{\circ} \mathrm{C}$ in a $1 \%$ buffered osmium tetroxide solution. The next day samples were given three 10 -min washes of cold $0.1 \mathrm{M}$ sodium cacodylate buffer. Specimens were dehydrated in a graded series of ethanol starting at $10 \%$ and proceeding through three $100 \%$ changes. A $2 \%$ uranyl acetate in $70 \%$ ethanol solution was used rather than just $70 \%$ ethanol to enhance conductivity and reduce charging effects. After the three $100 \%$ ethanol steps, the specimens were transferred to a pressure chamber in a Bal-Tec CPD 030 critical point dryer (Bal-Tec AG, Balzers, Liechtenstein) for artifact-free drying. The ethanol was gradually replaced by a transitional fluid, liquid carbon dioxide, and then critical point dried. The specimen was gradually brought to atmospheric pressure and mounted with double-sided sticky tape on aluminum stubs. The stubs were coated with $\approx 30 \mathrm{~nm}$ of gold-palladium in a Bal-Tec SCD 050 sputter coater (plasma coater), and viewed in a Hitachi S-4500 field emission scanning electron microscope (Hitachi Instruments, San Jose, Calif.). 


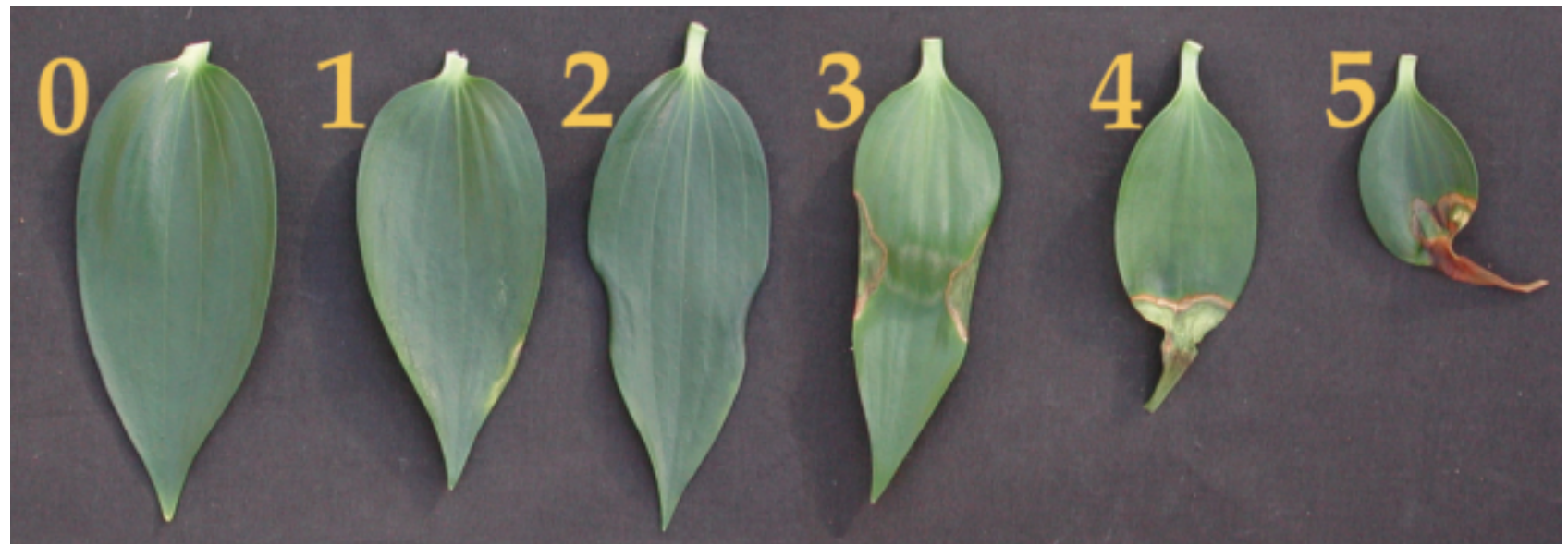

Fig. 1. An index of $0-5$ was used to describe the single leaf severity of upper leaf necrosis on Lilium 'Star Gazer': $0=$ no visible necrosis symptoms, $1=$ chlorotic spots, $2=$ curled leaf margin, $3=$ marginal necrosis, $4=$ dead leaf tip, and $5=$ more than $50 \%$ of the leaf area was necrotic.

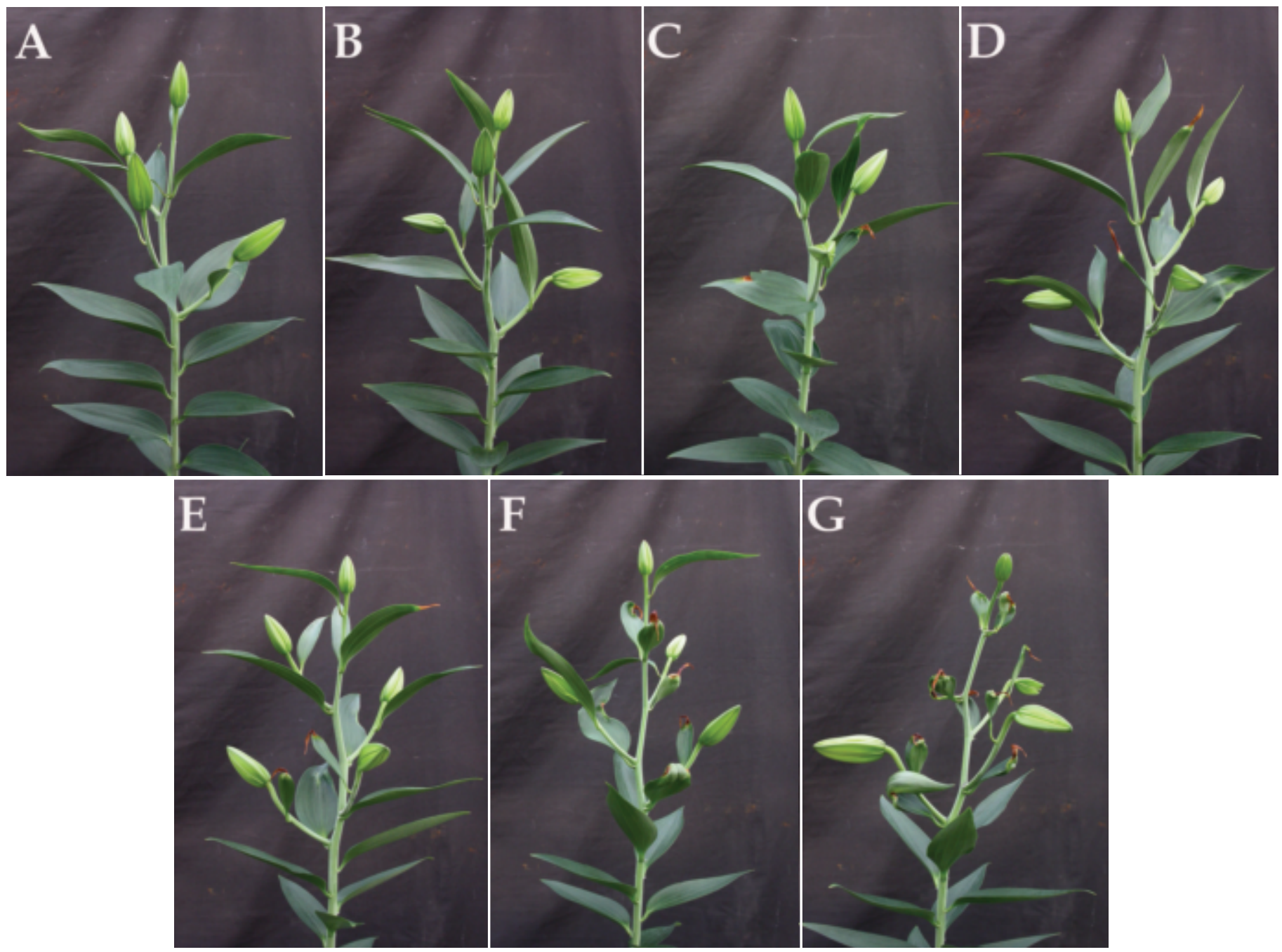

Fig. 2. Examples of plants expressing different levels of whole-plant severity: (A) 0 (healthy), (B) 5, (C) 10, (D) 15, (E) 20, (F) 25, and (G) 50. A plant with a severity index $<5$ exhibited only very light symptoms that would not be visible to the casual observer. 


\section{Results}

ULN SYMPTOMs. Upper leaf necrosis occurred only on young, expanding leaves. Generally, symptoms were observed 0 to $3 \mathrm{~d}$ before the leaf unfolded (data not presented). Initial symptoms were mostly on the leaf margin. When symptoms were very light, they appeared as tiny depressed spots on lower surface of the leaf, with average diameter of $\approx 0.5 \mathrm{~mm}$. The spots could be difficult to see with the naked eye. As severity increased, the spots developed a light chlorosis. Under SEM, the lower epidermis of the leaf had patches of depressed regions where cells had collapsed (Fig. 3C). In healthy tissues, cells surrounding the guard cells were turgid, and therefore the stomata were recessed from the lower epidermis (Fig. $3 \mathrm{~A}$ and B). In necrosed tissues, since the epidermal cells had collapsed, the stomata were no longer recessed (Fig. $3 \mathrm{C}$ and D). In some cases the contents of the cells in the depressed regions were extruded through the stomatal openings (Fig. 3D); quantification of this phenomenon was not attempted.

In severe cases, early stage symptoms of ULN appeared as water-soaked tissue areas that could be up to $2 \mathrm{~cm}$ long, and the tissue soon turned brown. This necrosed tissue caused the leaf to curl or distort as leaf growth continued. In more severe cases, necrosed areas developed inwards from both margins to the center. This apparently blocked translocation and led to leaf tip death. In these cases, the necrosed leaf was smaller since it was not fully expanded (Figs. 1 and 2). Necrosed leaves were occasionally purplish in color.

Flower buds were rarely affected by ULN, even though they were associated with highly distorted leaves (Fig. 2). While ULN incidence was as high as $86 \%$, only $3 \%$ of the plants had affected
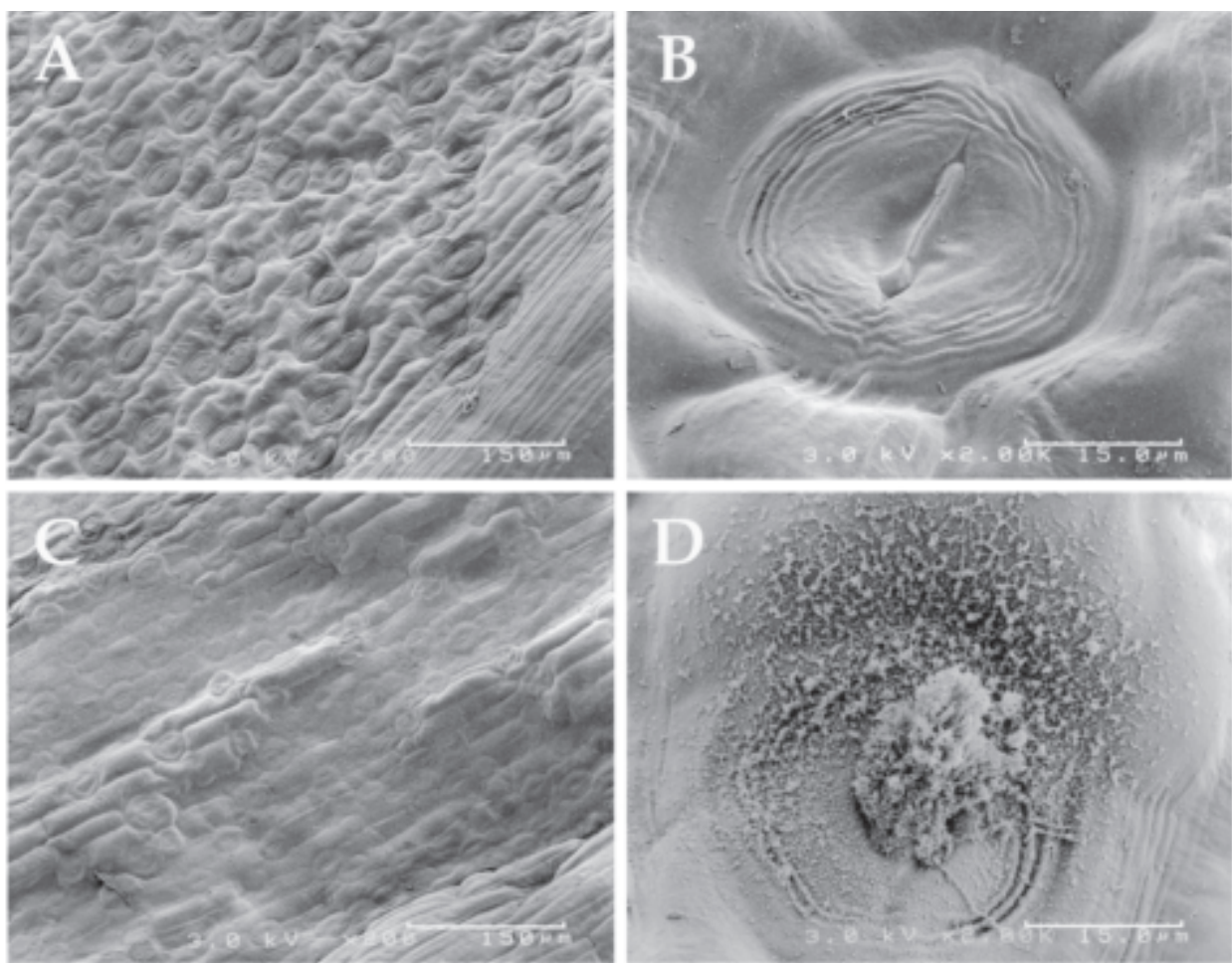

Fig. 3. Scanning electron micrographs of lower epidermis of healthy (upper panels) and necrosed (lower panels) leaves. Tissues were sampled from leaf margins $34 \mathrm{~d}$ after planting, at the stage when the leaf was just unfolded and upper leaf necrosis was beginning to exhibit. On necrosed tissue, the epidermal cells have collapsed, forming patches of depressed regions $(\mathbf{C})$. Compared with the turgid epidermal cells on the healthy tissue $(\mathbf{A}, \mathbf{B})$, the epidermal cells on the necrosed tissue have sunken inward, and sometimes resulted in their cell contents being extruded through the stomatal openings (D). flower buds (Table 1). Light ULN symptoms on flowers appeared as tepal tip distortion. The affected buds were able to flower normally. In rare and extreme cases, flower buds aborted.

SusCePTIBILITY TO ULN DEPENDS ON LEAF LOCATION. Upper leaf necrosis occurred only on the leaves associated with flower buds and the several leaves immediately below the flower buds (Table 2 and Fig. 2). Since plants varied in their leaf number, leaf location was defined relative to the bottom flower bud in these experiments. Generally, there are two leaves associated with each flower bud, such that the lower one is larger than the upper one. Table 2 shows that ULN incidence and severity both increased from lower to upper leaves, peaking on U2 (the 2nd leaf under the lowest bud) and U1, and then decreasing toward the top leaf. The five leaves under the flower buds (U1-U5) and the larger leaves associated with the 1st and 2nd flower buds (L1F and L2F) were most susceptible to ULN. Moreover, the smaller leaves associated with flower buds were less susceptible to ULN compared to larger ones. The incidence of ULN in smaller leaves was only $3.4 \%$, but $24.1 \%$ for larger leaves $(P<0.0001$ by chi-square test; $\mathrm{n}=1613$ ). The same trend was detected for ULN severity: Larger leaves had an average severity of 0.7 , smaller leaves a severity of $0.1(P<0.0001$ by ANOVA associated with the 5th flower bud (if there was one) or below the 10th leaf under the flower buds.

ULN STAGE. In the Spring Expt. and Summer Expt., three crops were planted at 2-week intervals to determine if planting date might affect ULN incidence and pattern of occurrence. Similar trends were seen in both the Spring Expt. and Summer Expt. Therefore, only data from the Summer Expt. are presented. In each crop, a high incidence of ULN was observed, and the incidence of ULN did not significantly differ among crops. Crop 1,2, and 3 had $91 \%, 85 \%$, and $83 \%$ necrosed plants, respectively (Table 1). From the mean of 300 plants that were grown from $16-18 \mathrm{~cm}$ bulbs, 'Star Gazer' began to exhibit ULN symptoms 35 DAP, 29 d after shoot emergence (DAE), when the U6 leaf was just unfolded, or when plant height was $32 \mathrm{~cm}$ (Table 1).

LEAF AND SOIL ANALYSIS. Foliar nutrient levels of both healthy and necrosed tissues were determined 45 DAP. Ca concentration in necrosed tissue was almost six times lower than the level of healthy tissue [i.e., $0.10 \%$ vs. $0.57 \%$ dry weight (DW)]. Besides $\mathrm{Ca}$, the concentrations of $\mathrm{Mg}, \mathrm{Mn}$, and $\mathrm{Cu}$ also were lower in necrosed leaves than normal ones, while $\mathrm{P}, \mathrm{K}$, and $\mathrm{Zn}$ were higher (Table 3). A negative association was seen between Ca concentration and ULN severity (Fig. 4). On an individual leaf basis, when the average $\mathrm{Ca}$ concentration dropped to $0.72 \%$ DW (severity index 1), light symptoms were noted. In very severely necrosed leaves (severity index 5), the Ca concentration was only $0.20 \%$ DW (Fig. 4). At this stage, soil was analyzed, and there was no difference in soil mineral nutrient levels 
Table 1. Data on upper leaf necrosis (ULN) of Lilium 'Star Gazer' from three crops, planted on 2, 16, and 30 Aug., respectively $(\mathrm{n}=100)$.

\begin{tabular}{|c|c|c|c|c|c|c|c|c|c|}
\hline & \multicolumn{2}{|c|}{ Necrosis } & \multicolumn{4}{|c|}{ Stage when ULN symptoms were first noted } & \multirow{2}{*}{$\begin{array}{l}\text { Plant ht at } \\
53 \text { DAP } \\
(\mathrm{cm})\end{array}$} & \multirow[b]{2}{*}{$\begin{array}{l}\text { Time to } \\
\text { anthesis } \\
\text { (d) }\end{array}$} & \multirow{2}{*}{$\begin{array}{c}\text { Plants with } \\
\text { abnormal } \\
\text { flowers } \\
(\%)\end{array}$} \\
\hline & $\begin{array}{c}\text { Incidence } \\
(\%)\end{array}$ & Severity & $\mathrm{DAP}^{\mathrm{z}}$ & $\mathrm{DAE}^{\mathrm{z}}$ & $\begin{array}{c}\text { Last } \\
\text { unfolded leaf }\end{array}$ & $\begin{array}{l}\text { Plant ht } \\
\text { (cm) }\end{array}$ & & & \\
\hline Crop 1 & $91^{\mathrm{y}}$ & $18.2 \mathrm{a}^{\mathrm{x}}$ & $38 \mathrm{a}$ & $30 \mathrm{a}$ & $\mathrm{U} 6.7^{\mathrm{W}} \mathrm{b}$ & $29.8 \mathrm{~b}$ & $46.3 \mathrm{~b}$ & $94 \mathrm{~b}$ & $6.0^{\mathrm{v}}$ \\
\hline Crop 2 & 85 & $11.3 \mathrm{~b}$ & $34 \mathrm{~b}$ & $28 \mathrm{~b}$ & $\mathrm{U} 6.2 \mathrm{ab}$ & $33.7 \mathrm{a}$ & $55.8 \mathrm{a}$ & $94 \mathrm{~b}$ & 0.0 \\
\hline Crop 3 & 83 & $12.0 \mathrm{~b}$ & $34 \mathrm{~b}$ & $28 \mathrm{~b}$ & U6.1 a & $33.6 \mathrm{a}$ & $55.4 \mathrm{a}$ & $100 \mathrm{a}$ & 3.0 \\
\hline Average & 86 & 13.8 & 35 & 29 & U6.4 & 32.3 & 52.5 & 96 & 3.0 \\
\hline
\end{tabular}

${ }^{\mathrm{z}} \mathrm{DAP}=$ days after planting, DAE $=$ days after shoot emergence.

${ }^{\mathrm{y}}$ Non-significant between crops by chi-square test, $P=0.23$.

${ }^{\mathrm{x}}$ Means in the column followed by a different letter are significantly different at $P \leq 0.05$ by Duncan's multiple range test.

${ }^{\mathrm{w}} \mathrm{U} 6$ means the $6^{\text {th }}$ leaf right beneath the bottom flower bud.

${ }^{\mathrm{v}}$ Significant between crops by chi-square test, $P=0.045$.

Table 2. Necrosis incidence and severity of leaves at different locations on Lilium 'Star

Gazer.' Buds are counted from the bottom of the plant, that is, the first bud is the lowest on the plant $(n=300)$.

\begin{tabular}{|c|c|c|}
\hline \multirow[b]{2}{*}{ Leaf location } & \multicolumn{2}{|c|}{ Necrosis $^{z}$} \\
\hline & Incidence $(\%)$ & Severity \\
\hline Smaller leaf associated with $8^{\text {th }}$ flower bud (S8F) & $0.0^{\mathrm{y}}$ & $0.0 \mathrm{~h}^{\mathrm{x}}$ \\
\hline Leaf L8F to leaf S6F & 0.0 & $0.0 \mathrm{~h}$ \\
\hline Larger leaf associated with $6^{\text {th }}$ flower bud (L6F) & 0.0 & $0.0 \mathrm{~h}$ \\
\hline Smaller leaf associated with $5^{\text {th }}$ flower bud (S5F) & 1.6 & $0.0 \mathrm{~h}$ \\
\hline Larger leaf associated with $5^{\text {th }}$ flower bud (L5F) & 4.7 & $0.1 \mathrm{~h}$ \\
\hline Smaller leaf associated with $4^{\text {th }}$ flower bud (S4F) & 2.0 & $0.1 \mathrm{~h}$ \\
\hline Larger leaf associated with $4^{\text {th }}$ flower bud (L4F) & 9.2 & 0.2 \\
\hline Smaller leaf associated with $3^{\text {rd }}$ flower bud (S3F) & 3.0 & $0.1 \mathrm{~h}$ \\
\hline Larger leaf associated with $3^{\text {rd }}$ flower bud (L3F) & 18.3 & $0.5 \mathrm{f}$ \\
\hline Smaller leaf associated with $2^{\text {nd }}$ flower bud (S2F) & 4.7 & $0.1 \mathrm{~h}$ \\
\hline Larger leaf associated with $2^{\text {nd }}$ flower bud (L2F) & 38.7 & $1.1 \mathrm{~d}$ \\
\hline Smaller leaf associated with $1^{\text {st }}$ flower bud (S1F) & 7.0 & $0.2 \mathrm{gh}$ \\
\hline Larger leaf associated with $1^{\text {st }}$ flower bud (L1F) & 59.3 & $2.0 \mathrm{c}$ \\
\hline $1^{\text {st }}$ leaf under buds (U1) & 78.7 & $2.7 \mathrm{a}$ \\
\hline $2^{\text {nd }}$ leaf under buds (U2) & 78.0 & $2.3 \mathrm{~b}$ \\
\hline $3^{\text {rd }}$ leaf under buds (U3) & 72.3 & $1.8 \mathrm{c}$ \\
\hline $4^{\text {th }}$ leaf under buds (U4) & 63.7 & $1.2 \mathrm{~d}$ \\
\hline $5^{\text {th }}$ leaf under buds (U5) & 48.0 & $0.7 \mathrm{e}$ \\
\hline $6^{\text {th }}$ leaf under buds (U6) & 33.3 & $0.4 \mathrm{fg}$ \\
\hline $7^{\text {th }}$ leaf under buds (U7) & 19.7 & $0.2 \mathrm{gh}$ \\
\hline $8^{\text {th }}$ leaf under buds (U8) & 10.7 & $0.1 \mathrm{~h}$ \\
\hline $9^{\text {th }}$ leaf under buds (U9) & 4.0 & $0.0 \mathrm{~h}$ \\
\hline $10^{\text {th }}$ leaf under buds (U10) & 0.3 & $0.0 \mathrm{~h}$ \\
\hline $11^{\text {th }}$ leaf under buds (U11) & 0.0 & $0.0 \mathrm{~h}$ \\
\hline Leaf U12 to leaf L2 & 0.0 & $0.0 \mathrm{~h}$ \\
\hline $1^{\text {st }}$ leaf from the bottom (L1) & 0.0 & $0.0 \mathrm{~h}$ \\
\hline
\end{tabular}

${ }^{\mathrm{z}}$ Necrosis incidence is defined as the percentage of leaves that have any level of symptom expressed. Necrosis severity of a leaf is graded using a scale from 0 (healthy) to 5 ( $>50 \%$ of the leaf area was necrotic).

${ }^{\mathrm{y}}$ Significantly different between locations by chi-square test, $P<0.0001$.

${ }^{x}$ Means in the column followed by a different letter are significantly different at $P \leq$ 0.05 by Duncan's multiple range test.

of $\mathrm{N}, \mathrm{P}, \mathrm{K}, \mathrm{Ca}, \mathrm{Mg}, \mathrm{Fe}, \mathrm{Mn}, \mathrm{Cu}$, and $\mathrm{Zn}$ between necrosed and healthy plants (data not shown). The Ca concentration in the soil mixes of healthy and necrosed groups were both $1.0 \%(P=0.95$ by ANOVA; $n=6$ ).

Time OF OCCURRENCE. Regardless the dates of planting, all three crops exhibited the same pattern of ULN occurrence (Fig. 5). In other words, ULN was not affected by different planting dates and occurred repeatedly and consistently. Upper leaf necrosis developed rapidly over a brief time period. All the necrosed plants were observed within a span of $12-14 \mathrm{~d}$ and $\approx 85 \%$ of necrosed plants began to show symptoms 30-40 DAP (Fig. 5). The incidence reached the peak (maximum appearance rate of first symptoms) $37 \mathrm{DAP}$ for Crop 1, 33 DAP for Crop 2, and 37 DAP for Crop 3. Once flower buds were visible, no further ULN developed.

EFFECT OF DAILY LIGHT INTEGRAL. To investigate if daily light integral initiated ULN, daily photosynthetically active radiation $(P A R)$ before ULN expression was measured (Fig. 5) and compared between three crops (Table 4). The average daily light integral (DLI) from $10 \mathrm{Aug}$. to 6 Oct. was $20.1 \mathrm{~mol} \cdot \mathrm{m}^{-2} \cdot \mathrm{d}^{-1}$. On the days that the necrosis rate exceeded $10 \%$, the DLI varied from 7.5 to 29.2 $\mathrm{mol} \cdot \mathrm{m}^{-2} \cdot \mathrm{d}^{-1}$. The DLI was in the range of 11.7 to $29.2 \mathrm{~mol} \cdot \mathrm{m}^{-2} \cdot \mathrm{d}^{-1}$ $1 \mathrm{~d}$ earlier, and 7.5 to $29.22 \mathrm{~d}$ earlier (Fig. 5). The high incidence of ULN occurrence seemed not directly associated with DLI. No given period of time (1-2, 1-4, or 1-6 d prior to the ULN peak) was identified when the light integral was consistently much higher or much lower than $20.1 \mathrm{~mol} \cdot \mathrm{m}^{-2} \cdot \mathrm{d}^{-1}$ in all three crops (Table 4 ). Average daily light integral received by Crop 1 was higher than other two crops (Table 4), but all three crops had a similar ULN pattern (Fig. 5). When ULN incidence peaked, Crop 1, Crop 2, and Crop $3 \mathrm{had}$ received total PAR of 690, 591, and $582 \mathrm{~mol} \cdot \mathrm{m}^{-2}$, respectively (Table 4 ).

EFFect of Light REDuction. Results from Shading Expt. 1 and Expt. 2 showed very similar trends (Table 5), thus, data presented here are mainly from Expt. 1. ULN severity increased as the level of shading increased. The control group had an average severity of 7.9 , while the $55 \%$ shading treatment had a significantly higher severity rating of 17.0 (Table 5). Leaf transpiration, photosynthesis, shoot growth rate, and leaf $\mathrm{Ca}$ concentration were all negatively correlated with shading levels. Leaf transpiration was significantly reduced by shading; the control group had transpiration of $1.40 \mathrm{mmol} \cdot \mathrm{m}^{-2} \cdot \mathrm{s}^{-1}$, but only 0.90 in the $55 \%$ shading treatment. Leaf Ca concentration followed same trend as transpiration. Average Ca concentration in all leaves was $1.69 \%$ DW in nonshaded plants, $1.50 \%$ in the $30 \%$ shading treatment, and $1.34 \%$ in the $55 \%$ shading treatment. Compared to control plants, shoot growth rate (DW grams per day) was reduced in the high shade treatment, but plant height was not. Relative humidity was not changed by shading treatments (Table 5).

This experiment was repeated beginning 20 Nov., 2 months after the first experiment. Results were broadly similar to those in Expt. 1 (Table 5). However, it is worth mentioning that ULN incidence and severity were higher in Expt. 2 than Expt. 1, corresponding to a daily light integral in Expt. 2 that was only $49 \%$ of that in Expt. 1 (Table 5).

\section{Discussion}

UPPER LEAF NECROSIS IS A CALCIUM DEFICIENCY DISORDER. The Ca concentration in necrosed tissue was extremely low. In Table 3 , it can be seen that the average Ca concentration in necrosed tissue was only $0.10 \%$ DW and $0.57 \%$ in healthy tissue. The range of $\mathrm{Ca}$ in necrosed tissue was $0.02 \%$ to $0.26 \%$, while healthy tissues ranged from $0.42 \%$ to $0.87 \%$ (data not shown). At this 
Table 3. Mineral nutrient concentration of necrosed and healthy tissue on Lilium 'Star Gazer' $45 \mathrm{~d}$ after planting $(\mathrm{n}=6)$.

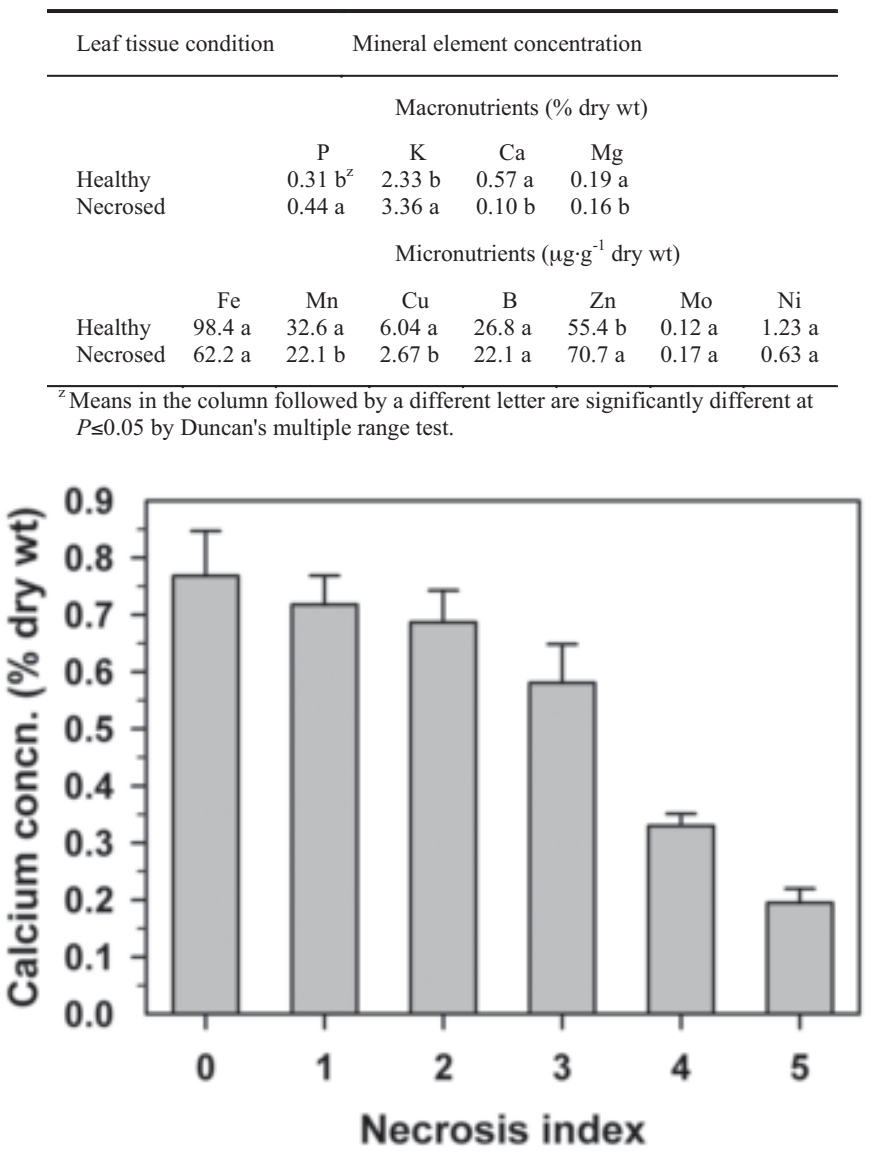

Fig. 4. Association between single leaf severity index and leaf calcium concentration at $45 \mathrm{~d}$ after planting. Each point represents the mean $\pm \mathrm{SE}$ of seven replicates.

stage (45 DAP), the critical Ca concentration associated with ULN on a tissue basis seemed to be $0.3 \%$ to $0.4 \%$ DW or less. On a single leaf basis, Ca concentration decreased significantly as the necrosed area increased (Fig. 4). Mills and Jones (1996) suggested the sufficient nutrient levels in newly matured leaves of easter lily at the stage prior to bud expansion as follows: $0.25 \%$ to $0.7 \% \mathrm{P}, 3.3 \%$ to $5.0 \% \mathrm{~K}, 0.6 \%$ to $1.5 \% \mathrm{Ca}, 0.2 \%$ to $0.7 \% \mathrm{Mg}$, 25-75 $\mu \mathrm{g} \cdot \mathrm{g}^{-1} \mathrm{~B}, 8-50 \mu \mathrm{g} \cdot \mathrm{g}^{-1} \mathrm{Cu}, 60-200 \mu \mathrm{g} \cdot \mathrm{g}^{-1} \mathrm{Fe}, 35-200 \mu \mathrm{g} \cdot \mathrm{g}^{-1}$ $\mathrm{Mn}$, and 20-200 $\mu \mathrm{g} \cdot \mathrm{g}^{-1} \mathrm{Zn}$. The Ca concentration of $0.10 \%$ in necrosed tissue on 'Star Gazer' lily was much less than the proposed sufficient $\mathrm{Ca}$ level for easter lily. Although concentrations of $\mathrm{Mg}, \mathrm{Mn}$, and $\mathrm{Cu}$ in necrosed tissue were also lower than the suggested values, the differences were not as notable as $\mathrm{Ca}$; and ULN symptoms do not resemble typical deficiency symptoms of these elements (Bergmann, 1992; Marschner, 1995; Robinson, 1984). The higher levels of $\mathrm{P}, \mathrm{K}$, and $\mathrm{Zn}$ in necrosed leaves did not exceed sufficiency levels for being toxic (Table 3).

Characteristics of ULN such as water-soaked tissue, marginal necrosis, and tip-burn are all typical $\mathrm{Ca}$ deficiency symptoms. For example, water soaked tissue on apples (Malus domestica Borkh.) (Faust et al., 1969), tipburn of lettuce (Lactuca sativa L.) (Collier and Tibbitts, 1982) and chinese cabbage (Brassica pekinensis Rupr.) (van Berkel, 1988), and marginal bract necrosis on poinsettia (Euphorbia pulcherrima Willd.) (Wissemeier, 1993) are all Ca deficiency symptoms. Calcium is well known to be important for maintaining membrane stability and cell integrity

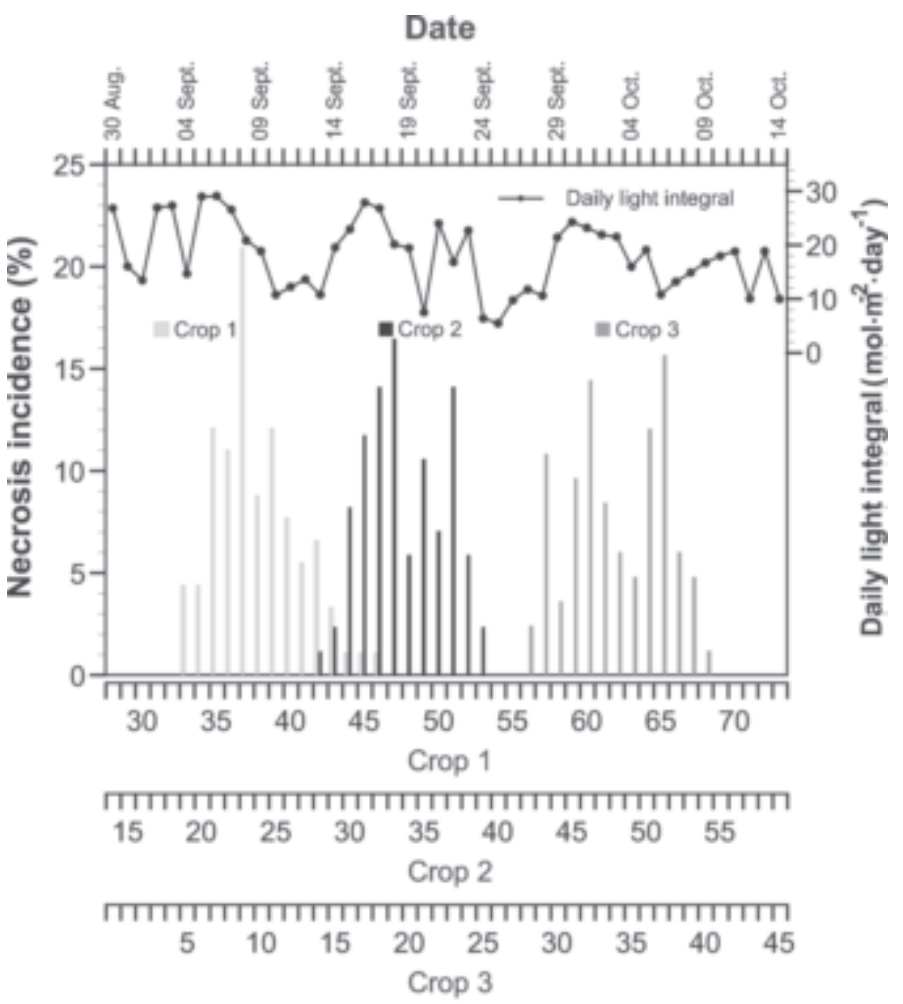

\section{Days after planting}

Fig. 5. Time of occurrence of upper leaf necrosis on Lilium 'Star Gazer' grown from 16-18 cm bulbs and its relationship to daily light integral. Necrosis data were collected each day and are the percentage of plants that first exhibited ULN symptoms on each indicated day. Crop 1, Crop 2, and Crop 3 were planted 2 , 16, and 30 Aug., respectively. Buds were visible at $\approx 50 \mathrm{~d}$ after planting (n $=100)$.

(Epstein, 1972). In the absence of Ca, membranes become leaky, and solutes are lost from cytoplasm (van Steveninck, 1965). In the study with SEM, we did observe that cells on necrosed tissue were collapsed and sometimes cell content was extruded through the stomatal openings (Fig. $3 \mathrm{C}$ and D). Similarly, it was found on potato sprouts with $\mathrm{Ca}$ deficiency that cytoplasm of necrotic cell was extruded to the epidermal surface (Lyshede, 1980).

When grown from smaller bulbs, 'Star Gazer' is much less susceptible to ULN. By growing these less-susceptible bulbs in Ca-free nutrient solution in sand culture, we readily induced ULN symptoms; ULN incidence increased from 13\% (control) to $100 \%$, and severity from 0.1 to 40 (Chang and Miller, 2003). When exogenous Ca was supplied by foliar sprays, ULN severity was significantly reduced. Fourteen daily sprays of $25 \mathrm{~mm}$ calcium nitrate reduced the severity from 18 to 2 (Chang et al., 2004). These data and the results of the current studies make a convincing case that ULN is a calcium-deficiency disorder. Our previous studies also disclosed that the Ca deficiency is attributed to combined physiological causes, including two major factors: 1) insufficient Ca supply from the bulb scales (Chang and Miller, 2003), and 2) reduced transpiration of young leaves due to leaf enclosure (Chang and Miller, 2004). Since lilies are able to translocate a limited amount of $\mathrm{Ca}$ from the bulb scales to the lower leaves (Chang and Miller, 2003), ULN symptoms occurs only on upper leaves.

INDICATORS OF GROWTH STAGE THAT DEFINE THE START OF SYMPTOM DEVELOPMENT. 'Star Gazer' began to exhibit symptoms 30-40 DAP (Fig. 5), and were free from further ULN development after 
Table 4. Photosynthetically active radiation (PAR) during the growth period until upper leaf necrosis (ULN) incidence peaked. Crop 1 was planted 2 Aug. with ULN peaking $37 \mathrm{~d}$ after planting (DAP). Crop 2 was planted 16 Aug. with ULN peaking 33 DAP. Crop 3 was planted 30 Aug. with ULN peaking 37 DAP.

\begin{tabular}{|c|c|c|c|}
\hline \multirow[b]{2}{*}{ Period } & \multicolumn{3}{|c|}{$\operatorname{PAR}\left(\mathrm{mol} \cdot \mathrm{m}^{-2} \cdot \mathrm{d}^{-1}\right)$} \\
\hline & Crop 1 & Crop 2 & Crop 3 \\
\hline $3^{\text {rd }}$ day prior to the peak & 29.0 & 23.0 & 21.5 \\
\hline $2^{\text {nd }}$ day prior to the peak & 29.2 & 27.9 & 16.0 \\
\hline $1^{\text {st }}$ day prior to the peak & 26.6 & 26.9 & 19.1 \\
\hline The day peaked & 20.9 & 20.1 & 10.8 \\
\hline $\begin{array}{l}\text { Average daily integral, } \\
1-2 \text { d prior to the peak }\end{array}$ & 27.9 & 27.4 & 17.5 \\
\hline $\begin{array}{l}\text { Average daily integral, } \\
1-4 \text { d prior to the peak }\end{array}$ & 24.9 & 24.3 & 19.6 \\
\hline $\begin{array}{l}\text { Average daily integral, } \\
1-6 \text { d prior to the peak }\end{array}$ & 25.6 & 20.3 & 21.0 \\
\hline $\begin{array}{l}\text { Average daily integral, from } \\
\text { shoot emergence to the peak }\end{array}$ & 23.0 & 21.1 & 18.2 \\
\hline $\begin{array}{l}\text { Accumulated integral, from } \\
\text { shoot emergence to the peak } \\
\left(\mathrm{mol} \cdot \mathrm{m}^{-2}\right)\end{array}$ & 690.4 & 591.2 & 582.1 \\
\hline
\end{tabular}

flower buds were visible ( $\approx 50$ DAP). While this is a relatively short period, there is a need for a better indicator to accurately determine the timing of remedial treatments. Several indicators may be used, such as DAP, DAE, plant height, and location of the last unfolded leaf, as shown on Table 1. In general, DAE is a better parameter than DAP. The time period needed for the shoot to emerge was highly dependent on the length of the cold storage period: the longer the bulbs were stored after digging, the faster they emerged. Therefore, DAE was less variable than DAP between the three crops as shown in Table 1. Variation was also seen when plant height was used as an indicator. 'Star Gazer' began to show ULN symptoms when they were 24 to $44 \mathrm{~cm}$ tall, even though plants were in the same developmental stage as defined by unfolded leaves. Most plants began to show ULN when the sixth or seventh leaf below the flower buds (U6 or U7) was just unfolded (Table 1). Comparing the behavior of the three groups of plants, the probability values for DAP, DAE, plant height, were all $P<0.0001$, but it was 0.07 for "location of the last unfolded leaf" (by ANOVA; $\mathrm{n}=100$ ). This suggests that "location of the last unfolded leaf" is the best indicator, since it was less affected by different planting dates.

LIGHT DOES NOT DIRECTLY INITIATE ULN. Anecdotal evidence in the lily forcing industry suggests that this disorder is "triggered" by a bright day following a prolonged period of dark, cloudy weather. We tried to determine if an extremely high or extremely low light integral during a certain period of time would induce ULN. If so, we should see a consistent light level at some stage before the incidence peaked in all three crops. Data in Table 4 suggest that DLI was not related to the onset of ULN. Abrupt changes in irradiance also did not initiate ULN, since we observed new ULN events after both continuous cloudy or sunny days. We also excluded the possibility that ULN was damage caused by high light intensity, because some symptoms occurred when leaves were still enclosed by outer leaves and not exposed to direct sunlight. The peak of ULN occurrence was likely caused by factors within the plant itself, rather than environmental factors, as all three crops exhibited the same occurrence pattern regardless planting date and daily light integral (Fig. 5). Our previous study indicated that susceptible period started when the plant was entering a rapid growth phase, while Ca reserved in bulb scales were rapidly declining (Chang and Miller, 2003). The imbalance between Ca demand (by the leaves) and supply (from the scales and roots) seems to be the major cause of ULN occurrence pattern.

LIGHT REDUCTION INCREASES ULN. It is well known that high irradiance exacerbates Ca deficiency disorders since it promotes rapid growth and increases $\mathrm{Ca}$ demand beyond that easily met by root uptake (Collier and Tibbitts, 1982; Ho et al., 1993; Tibbitts and Rao, 1968). Nevertheless, due to the lack of information on the effects of light reduction, the above finding may be incorrectly extrapolated to the conclusion that low irradiance would reduce $\mathrm{Ca}$ deficiency disorders.

Previously, we have shown ULN in 'Star Gazer' was greatly increased by reducing transpiration of young leaves (Chang and Miller, 2004); in the current study, we demonstrated that Lilium 'Star Gazer'suffers greater calcium deficiency (ULN) in low-irradiance environments since leaf transpiration was decreased, resulting in reduced leaf Ca concentration (Table 5). Furthermore, Shading Expt. 2, which began on 20 Nov., had much more ULN than in the earlier Expt. 1, planted 18 Sept. The daily light integral in Expt. 2 was $4.6 \mathrm{~mol} \cdot \mathrm{m}^{-2} \cdot \mathrm{d}^{-1}$, only about half of that in the earlier experiment $\left(9.3 \mathrm{~mol} \cdot \mathrm{m}^{-2} \cdot \mathrm{d}^{-1}\right.$, Table 5$)$. During winter greenhouse cropping in Ithaca, N.Y., low irradiance is the dominant environmental factor promoting ULN. 
Although we don't have data specifically on the effects of supplemental lighting on the occurrence of ULN, Treder (2001) found that 'Star Gazer' grown with artificial light had approximately double the leaf $\mathrm{Ca}$ level of nonilluminated plants. We would thus suggest growers use supplemental lighting during winter periods to reduce the disorder.

\section{Literature Cited}

Berghoef, J. 1986. Effect of calcium on tipburn of Lilium 'Pirate'. Acta Hort. 177:433-438.

Berghoef, J., G.S.J. Kappelhof, and B. Willems. 1981. Control of leaf scorch on lilies, cv. Pirate, requires further research. Vakblad voor de Bloemisterij 36:22-23.

Bergmann, W. 1992. Nutritional disorders of plants: Development, visual and analytical diagnosis. Gustav Fischer Verlag, Jena, Germany.

Chang, Y.C., K. Grace-Martin, and W.B. Miller. 2004. Efficacy of exogenous calcium applications for reducing upper leaf necrosis in Lilium 'Star Gazer'. HortScience 39:272-275.

Chang, Y.C. and W.B. Miller. 2003. Growth and calcium partitioning in Lilium 'Star Gazer' in relation to leaf calcium deficiency. J. Amer. Soc. Hort. Sci. 128:788-796.

Chang, Y.C. and W.B. Miller. 2004. The relationships between leaf enclosure, transpiration, and upper leaf necrosis on Lilium 'Star Gazer'. J. Amer. Soc. Hort. Sci. 129:128-133.

Collier, G.F. and T.W. Tibbitts. 1982. Tipburn of lettuce. Hort. Rev. 4:49-65.

Dunham, C.W. and D.F. Crossan. 1959. Factors in tip-burn injury on leaves of easter lilies. Proc. Amer. Soc. Hort. Sci. 74:704-710.

Epstein, E. 1972. Mineral nutrition of plants: Principles and perspectives. Wiley, New York.

Faust, M., C.B. Shear, and M.W. Williams. 1969. Disorders of carbohydrate metabolism of apples (watercore, internal breakdown, low temperature and carbon dioxide injuries). Bot. Rev. 35:169-194.

Glauert, A.M. 1975. Fixation, dehydration and embedding of biological specimens, p. 1-207. In: A.M. Glauert (eds.). Practical methods in electron microscopy. Vol. 3. North-Holland, Amsterdam, The Netherlands.
Ho, L.C., R. Belda, M. Brown, J. Andrews, and P. Adams. 1993. Uptake and transport of calcium and the possible causes of blossom-end rot in tomato. J. Expt. Bot. 44:509-518.

Lyshede, O.B. 1980. Structural studies on healthy and necrotic young epidermal cells of growing potato sprouts. New Phytol. 84:723-727.

Marousky, F.J. 1979. Classical leaf scorch: Boron or fluoride, p. 55-59. In: The lily yearbook 1978. North Amer. Lily Soc., Geneva, N.Y.

Marschner, H. 1995. Mineral nutrition of higher plants. Academic, London.

Miller, W.B. 1992. Easter and hybrid lily production-Principles and practice. Timber Press, Portland, Ore.

Mills, H.A. and J.B. Jones. 1996. Plant analysis handbook II. MicroMacro Publishing, Athens, Ga.

Morgan, M.F. 1941. Chemical soil diagnosis by the Universal Soil Testing System. Connecticut Agr. Expt. Sta. Bul. 450.

Robinson, J.B.D. 1984. Diagnosis of mineral disorders in plants. Chemical Publishing, New York.

Seeley, J.G. 1950. Mineral nutrient deficiencies and leaf burn of Croft easter lilies. Proc. Amer. Soc. Hort. Sci. 56:439-445.

Simon, E.W. 1978. The symptoms of calcium deficiency in plants. New Phytol. 80:1-15.

Stuart, N.W., W. Skou, and D.C. Kiplinger. 1952. Further studies on cause and control of leaf scorch of Croft easter lily. Proc. Amer. Soc. Hort. Sci. 60:434-438.

Tibbitts, T.W. and R.R. Rao. 1968. Light intensity and duration in the development of lettuce tipburn. Proc. Amer. Soc. Hort. Sci. 93:454-461.

Treder, J. 2001. The effect of light and nutrition on growth and flowering of oriental lilies. Acta Hort. 548:523-528.

van Berkel, N. 1988. Preventing tipburn in chinese cabbage by high relative humidity during the night. Neth. J. Agr. Sci. 36:301-308.

van Nes, I.C. 1979. Research on leaf scorch of lilies cv. Pirate. Vakblad voor de Bloemisterij 34:36-37.

van Steveninck, R.F.M. 1965. The significance of calcium on the apparent permeability of cell membranes and the effects of substitution with out divalent ions. Physiol. Plant. 18:54-69.

Wissemeier, A.H. 1993. Marginal bract necrosis in poinsettia cultivars and the relationship to bract calcium nutrition. Gartenbauwissenschaft 58:158-163. 